\title{
Genetic variability, correlated response and path analysis of yield and yield contributing traits of spring wheat
}

\author{
D.A.N. Majumder ${ }^{1}$, A.K.M. Shamsuddin², M.A. Kabir ${ }^{3}$ and L. Hassan ${ }^{2}$ \\ ${ }^{1}$ Department of Biotechnology, Bangladesh Agricultural University, Mymensingh-2202 \\ ${ }^{2}$ Department of Genetics and Plant Breeding, Bangladesh Agricultural University, \\ Mymensingh \\ ${ }^{3}$ Department of Horticulture, Hajee Mohammad Danesh Sc.\& Tech. Univ., Dinajpure
}

\begin{abstract}
Twenty spring wheat varieties were studied to find out genetic variability and genetic association for grain yield and its component characters. Both genotypic and phenotypic variances were highly significant in all the traits with little higher phenotypic variations as usual. Similarly, the low differences between the phenotypic and genotypic coefficients of variations indicated low environmental influences on the expression of these characters. High heritability coupled with high genetic advance were obtained with plant height, grains per spike, 100-grain weight, harvest index and grain yield. Genotypic correlation coefficients were higher than the corresponding phenotypic correlation coefficients in most of the traits. Spikes per plant, grains per spike, spike length, 100-grain weight and harvest index were the most important characters which possessed positive association with grain yield. Path coefficient analysis revealed that among the different yield contributing characters spike per plant, grains per spike, 100-grain weight and harvest index influenced grain yield per plant directly. The direct effects of these characters on grain yield were positive and considerably high. Moreover, harvest index, days to maturity and spikes per plant had positive and higher indirect effect on grain yield through grains per spike. Thus selection for yield in spring wheat through these characters would be effective.
\end{abstract}

Keywords: Variability, Selection indices, Wheat

\section{Introduction}

Grain yield is the principal character of a cereal crop. This is a complex quantitative character, which is influenced by a number of yield contributing characters. So, the selection for desirable types should not only be based on yield, the other yield components should also be considered. Direct selection for yield is often misleading in wheat because wheat yield is polygenically controlled. For effective utilization of the genetic stock in crop improvement, information of mutual association between yield and yield components is necessary. It is, therefore, necessary to know the correlation of various component characters with yield and among themselves. The correlation coefficients between yield and yield components usually show a complex chain of interacting relationship. Path coefficient analysis partitions the components of correlation coefficient into direct and indirect effects and illuminates the relationship in a more meaningful way. The success of a breeding program depends largely upon the amount of genetic variability present in the population and the extent to which the desired traits are heritable. Therefore, an attempt was undertaken to estimate genetic variability, association among desired traits and their direct and indirect effects towards grain yield of wheat.

\section{Materials and Methods}

The experiment was conducted at the experimental Farm of the Department of Genetics and Plant Breeding, Bangladesh Agricultural University (BAU), Mymensingh during the rabi season of 2000-2001. The experiment consisted of 20 spring wheat (Triticum aestivum L.) genotypes (varieties or lines). These materials were collected from the Department of Genetics and Plant Breeding, BAU, Mymensingh. The name, origin and source of these materials are shown in Table1. 
Table 1. List of twenty spring wheat genotypes with their origin and source

\begin{tabular}{|l|l|l|l|l|l|l|l|}
\hline $\begin{array}{l}\text { Entry } \\
\text { No }\end{array}$ & Genotypes & $\begin{array}{l}\text { Breeder } \\
\text { Institute }\end{array}$ & $\begin{array}{l}\text { Country of } \\
\text { Origin }\end{array}$ & $\begin{array}{l}\text { Entry } \\
\text { No }\end{array}$ & Genotypes & $\begin{array}{l}\text { Breeder } \\
\text { Institute }\end{array}$ & Country of Origin \\
\hline 1 & Sonalika & BARI & India & 11 & BAW-936 & BARI & Bangladesh \\
\hline 2 & Mayoor & BARI & Bangladesh & 12 & SA-92 & CIMMYT & Mexico \\
\hline 3 & Kanchan & BARI & Bangladesh & 13 & Sawghat & BARI & Bangladesh \\
\hline 4 & BAW-677 & BARI & Bangladesh & 14 & Ananda & BARI & Bangladesh \\
\hline 5 & Kalyansona & IARI & India & 15 & Chyria-3 & CIMMYT & Mexico \\
\hline 6 & BAW-456 & BARI & Bangladesh & 16 & Seri-82 & CIMMYT & Mexico \\
\hline 7 & Anza & CIMMYT & Mexico & 17 & Wahan & BARI & Pakistan \\
\hline 8 & Gourav & BARI & Bangladesh & 18 & BAW-56 & BARI & Bangladesh \\
\hline 9 & Rawal & CIMMYT & Pakistan & 19 & DSN-29 & CIMMYT & Mexico \\
\hline 10 & Kheri & BARI & Bangladesh & 20 & Peacock & CIMMYT & Mexico \\
\hline
\end{tabular}

The seeds of twenty genotypes were sown on November 22, 2000 in a randomized complete block design with 3 replications. The plot size was $2 \mathrm{~m} \times 2 \mathrm{~m}$ with the spacing of $25 \mathrm{~cm}$ between the rows and $5 \mathrm{~cm}$ between plants in the same row. Fertilizers were applied @ 200:200:80:6000 kg of urea, TSP, MP and cow dung per hectare respectively. Intercultural operations and pest control measures were done as and when necessary. Since different genotypes matured at different times, harvesting was completed by 16th to 27th March 2001. Harvesting was done by uprooting of plants and boarder rows/ plants were omitted for collection of samples.

Observation was made from ten randomly selected plants and data were taken on plant height (PH), spikes per plant (SP), spike Length (SL), grains per spike (GS), 100-grain weight $(\mathrm{GW})$, days to maturity (DM), harvest Index $(\mathrm{HI})$ and grain yield per plant $(\mathrm{g})$. Analysis of variance was performed by computer using MSTAT-C software. The test of significance was done by F-test. Duncan's New Multiple Range Test (DMRT) was also done using MSTAT-C. Genotypic coefficients of variation (GCV) and phenotypic coefficients of variation (PCV) were estimated according to Burton and De Vane (1953); heritability in broad sense $\left(h^{2}{ }_{b}\right)$, genetic advance (GA) and genetic advance as \% of mean (GAPM) were calculated following Hanson et al. (1956); correlation coefficients were estimated according to Al-Jibouri et.al(1958) and path coefficient analysis was done following Dewy and Lu (1959).

\section{Results and Discussion}

\section{Genetic variability and mean performance of traits}

The analyses of variances revealed significant variations among the genotypes for all the characters (Table 2). The extent of variability for any character is very important for the improvement of a crop through breeding. The variability of the characters was measured by range, GCV and PCV. Mean, range, $S^{2} g, S^{2} p, S^{2} e, G C V, P C V, h^{2} b, G A$ and GAPM for all traits are given in Table 3. 
Table 2. Analysis of variance (mean square) for yield and yield contributing characters in $\mathbf{2 0}$ spring wheat

\begin{tabular}{|l|c|c|c|}
\hline \multirow{2}{*}{ Plant characters } & \multicolumn{3}{c|}{ Sources of variation } \\
\cline { 2 - 4 } & Replication (d.f.2) & Genotypes (d.f. 19) & Error (d.f. 38) \\
\hline Plant height (cm) & 4.75 & $365.62^{\star \star}$ & 4.566 \\
\hline Spikes per plant (no.) & 0.28 & $0.82^{\star \star}$ & 0.237 \\
\hline Spike length (cm) & $2.17^{\star \star}$ & $2.74^{\star \star}$ & 0.490 \\
\hline Grains per spike (no.) & 1.23 & $142.34^{\star \star}$ & 8.520 \\
\hline 100-grain weight (g) & 0.15 & $1.73^{\star \star}$ & 0.068 \\
\hline Days to maturity (days) & 1.32 & $21.33^{\star \star}$ & 1.054 \\
\hline Harvest index (\%) & $31.55^{\star \star}$ & $65.11^{\star \star}$ & 4.106 \\
\hline Grain yield per plant (g) & 0.56 & $3.12^{\star \star}$ & 0.428 \\
\hline
\end{tabular}

** =highly significant at $1 \%$ level, d.f. = degree of freedoms

Among the characters; spike length, grains per spike, 100-grain weight, harvest index and grain yield displayed more than $15 \%$ variation at phenotypic level, which could be considered as high enough. At genotypic level, grains per spike, 100-grain weight, harvest index and grain yield had more than $15 \%$ variation and others had less than $15 \%$ variation. PCV were slightly higher than GCV in case of plant height, 100-grain weight and days to maturity, indicating presence of environmental influence on the expression of these characters. The other characters; such as spikes per plant, spike length, grains per spike and grain yield showed considerably higher PCV than GCV which indicated marked influence of environment on the expression of these characters. Amin et al. (1992) also reported similar result for durum wheat. They observed that spikes per plant had high phenotypic coefficient of variation but its genotypic coefficient of variation was much low suggesting that the character spikes per plant was influenced by environmental factors. They also reported that genotypic coefficient of variation was high for grain yield followed by grains per spike and harvest index and lowest for days to maturity. These results are in close agreement with present study. High GCV and PCV were recorded for grains per spike, 100-grain weight and grain yield per plant but it was moderate for plant height spikes per plant, spike length, and harvest index. Days to maturity exhibited low genotypic as well as phenotypic coefficient of variation in the present study, which may be due to presence of both positive and negative alleles in the population. The findings were almost supported by Ehdaie and Waines (1989) who observed high GCV and PCV for number of grains per spike, 100-grain weight and grain yield per plant. But they obtained low coefficients of variation for days to maturity. The study of heritability indicates that the characters plant height, 100-grain weight, grains per spike, days to maturity, harvest index, grain yield and spike length were highly heritable. Only spikes per plant was moderately heritable indicating that the character was more influenced by environment. Although high heritability estimate have been found to be effective in the selection of superior genotypes on the basis of phenotypic performance, Johnson et al. (1955) suggested that heritability estimates along with genetic advance will be more useful in predicting the effect for selecting the best individual. The analysis of genetic advance in percentage of mean showed that the characters; plant height, grains per spike, 100-grain weight, harvest index and grain yield indicated good response to selection. These characters had more than $20 \%$ expected genetic advance under selection. Days to maturity, spike length and spikes per plant had minimum genetic advance in percentage of mean. These characters had also less phenotypic and genotypic coefficients of variation indicating that they were less important to selection. Among these characters 100-grain weight, grains per spike, harvest index and grain yield had high phenotypic and genotypic coefficient of variation associated with high heritability suggests that selection for these characters would be effective. Singh et al. (1978) also found high genetic advance associated with high heritability for grains per spike and 100-grain weight for macaroni wheat. Spikes per plant had low genetic advance 
associated with medium heritability. Low heritability with low genetic advance for this character was also reported by Balchand and Lodhi (1994). They said that poor estimates of heritability and genetic advance were due to the influence of environment on this trait. Amin et al. (1992) also reported low genotypic and phenotypic coefficient of variation, low heritability and low genetic advance for spikes per plant. This report supports the present findings. The high heritability estimates along with low genetic advance indicates that nonadditive type of gene action and genotype-environment interaction plays a significant role in the expression of the traits as observed in days to maturity in the present study. Plant height, spike length, grains per spike and 100- grain weight had high heritability with high genetic advance in percentage of mean making these four characters most important in the selection of modern wheat. High GCV, PCV, heritability and GA\% of mean for grains per spike and 100-grain weight suggested that these two characters could be transmitted to the hybrid progeny and phenotypic selection based on these would be effected.

Table 3. Estimates of genetic parameters for eight characters in spring wheat

\begin{tabular}{|l|c|c|c|c|c|c|c|c|c|c|}
\hline Characters & Range & Mean & $\mathrm{S}^{2} \mathrm{~g}$ & $\mathrm{~S}^{2} \mathrm{e}$ & $\mathrm{S}^{2} \mathrm{p}$ & $\mathrm{GCV}$ & $\mathrm{PCV}$ & $\mathrm{h}^{2} \mathrm{~b}$ & $\mathrm{GA}$ & $\mathrm{GAPM}$ \\
\hline $\mathrm{PL}$ & $78.93-129.2$ & 94.84 & 120.32 & 4.66 & 124.98 & 11.57 & 11.79 & 96.283 & 22.18 & 23.39 \\
\hline $\mathrm{SP}$ & $3.53-5.54$ & 04.13 & 00.20 & 0.24 & 00.44 & 09.63 & 14.33 & 45.140 & 0.61 & 13.31 \\
\hline $\mathrm{SL}$ & $7.52-11.23$ & 08.54 & 00.75 & 0.49 & 01.24 & 09.54 & 12.26 & 60.521 & 1.39 & 15.27 \\
\hline GS & $16.37-84.07$ & 36.79 & 44.61 & 8.52 & 53.13 & 20.68 & 22.54 & 83.964 & 12.61 & 39.06 \\
\hline GW & $3.19-5.28$ & 04.28 & 00.56 & 0.07 & 00.63 & 17.42 & 18.46 & 89.091 & 1.45 & 33.88 \\
\hline DM & $107.0-112.3$ & 110.97 & 06.76 & 1.05 & 07.81 & 02.34 & 02.52 & 86.512 & 4.98 & 4.49 \\
\hline HI & $15.28-32.63$ & 26.53 & 20.34 & 4.11 & 24.45 & 16.98 & 18.61 & 83.204 & 8.47 & 31.90 \\
\hline GY & $2.95-7.07$ & 04.90 & 00.90 & 0.43 & 01.33 & 19.34 & 23.50 & 67.754 & 1.61 & 32.82 \\
\hline
\end{tabular}

Legend: $\mathrm{PL}=$ Plant height, $\mathrm{SP}=$ Spikes per plant, $\mathrm{SL}=$ Spike length, $\mathrm{GS}=$ Grains per spike, $\mathrm{GW}=100-$ Grain weight, $\mathrm{DM}=$ Days to maturity, $\mathrm{HI}=$ Harvest Index, $\mathrm{GY}=$ Grain Yield per plant, $\mathrm{S}^{2} \mathrm{~g}$, =Genotypic variance, $\mathrm{S}^{2} \mathrm{e}=$ Environmental variance, $S^{2} p=$ Phenotypic variance, $G C V=$ Genotypic coefficient of variation, $P C V=$ Phenotypic coefficient of variation, $\mathrm{h}^{2} \mathrm{~b}=$ Broad sense heritability, $\mathrm{GA}=$ Genetic advance, GAPM= Genetic advance in (\%) of mean.

\section{Character association}

Mutual relationship between grain yield and its contributing characters (Table 4.) revealed that in most of the cases the genotypic correlation coefficient were higher than the corresponding phenotypic correlation coefficient indicating strong inherent relation between the traits but suppressing effect of the environment, which modified the phenotypic expression of these characters by reducing phenotypic coefficient values. Such environmental influence in reducing correlation coefficients in bread wheat was also reported by Agarawal et al. (1997) and Deswal et al. (1997).

From the study, grain yield per plant was positively and significantly correlated with grains per spike and harvest index both at genotypic and phenotypic levels. It suggests that yield per plant would increase with increase of these characters. Spikes per plant, spike length and 100-grain weight were positively correlated with grain yield but the values were non significant. Among the studied characters spikes per plant and grains per spike are the primary yield components and harvest index is the most important physiological trait. Similar association in winter wheat was also reported by Sharma et al. (1995) and Shoran (1995). 
Table 4. Estimates of genotypic $\left(r_{g}\right)$ and phenotypic $\left(r_{p}\right)$ correlation coefficients between grain yield/plant and its eight contributing characters in spring wheat

\begin{tabular}{|c|c|c|c|c|c|c|c|c|}
\hline Characters & & $\begin{array}{l}\text { Spikes } \\
\text { per plant } \\
\text { (no.) }\end{array}$ & $\begin{array}{c}\text { Spike } \\
\text { length } \\
(\mathrm{cm})\end{array}$ & $\begin{array}{c}\text { Grains per } \\
\text { spike } \\
\text { (no.) }\end{array}$ & $\begin{array}{c}\text { 100-grain } \\
\text { weight } \\
\text { (g) }\end{array}$ & $\begin{array}{l}\text { Days to } \\
\text { maturity } \\
\text { (days) }\end{array}$ & $\begin{array}{c}\text { Harvest } \\
\text { index } \\
(\%)\end{array}$ & $\begin{array}{c}\text { Grain } \\
\text { yield } \\
(\mathrm{g})\end{array}$ \\
\hline Plant height $(\mathrm{cm})$ & $\begin{array}{l}r_{g} \\
r_{p}\end{array}$ & $\begin{array}{l}-0.048 \\
-0.033\end{array}$ & $\begin{array}{l}-0.165 \\
-0.078\end{array}$ & $\begin{array}{l}-0.057 \\
-0.048\end{array}$ & $\begin{array}{r}0.001 \\
-0.001\end{array}$ & $\begin{array}{l}-0.187 \\
-0.149\end{array}$ & $\begin{array}{l}-0.294 \\
-0.265\end{array}$ & $\begin{array}{l}-0.193 \\
-0.146\end{array}$ \\
\hline Spikes per plant (no.) & $\begin{array}{l}r_{g} \\
r_{p}\end{array}$ & & $\begin{array}{l}-0.339 \\
-0.083 \\
\end{array}$ & $\begin{array}{l}0.231 \\
0.372 \\
\end{array}$ & $\begin{array}{l}-0.791 \\
-0.538^{\star *}\end{array}$ & $\begin{array}{l}0.292 \\
0.201\end{array}$ & $\begin{array}{l}0.171 \\
0.220 \\
\end{array}$ & $\begin{array}{l}0.008 \\
0.381 \\
\end{array}$ \\
\hline Spike length (cm) & $\begin{array}{l}r_{g} \\
r_{p}\end{array}$ & & & $\begin{array}{l}0.135 \\
0.169 \\
\end{array}$ & $\begin{array}{l}0.296 \\
0.240 \\
\end{array}$ & $\begin{array}{l}0.063 \\
0.029 \\
\end{array}$ & $\begin{array}{l}0.111 \\
0.133 \\
\end{array}$ & $\begin{array}{l}0.252 \\
0.259 \\
\end{array}$ \\
\hline Grains per spike (no.) & $\begin{array}{l}r_{g} \\
r_{p}\end{array}$ & & & & $\begin{array}{l}-0.547 \\
-0.483^{*} \\
\end{array}$ & $\begin{array}{l}0.363 \\
0.321 \\
\end{array}$ & $\begin{array}{l}0.373 \\
0.356 \\
\end{array}$ & $\begin{array}{l}0.590 \\
0.635^{\star *}\end{array}$ \\
\hline 100-grain weight (g) & $\begin{array}{l}r_{g} \\
r_{p}\end{array}$ & & & & & $\begin{array}{l}-0.361 \\
-0.356 \\
\end{array}$ & $\begin{array}{l}-0.071 \\
-0.049 \\
\end{array}$ & $\begin{array}{l}0.051 \\
0.015 \\
\end{array}$ \\
\hline Days to maturity (days) & $\begin{array}{l}r_{g} \\
r_{p}\end{array}$ & & & & & & $\begin{array}{l}-0.098 \\
-0.119 \\
\end{array}$ & $\begin{array}{l}-0.087 \\
-0.042 \\
\end{array}$ \\
\hline Harvest Index (\%) & $\begin{array}{l}r_{g} \\
r_{p}\end{array}$ & & & & & & & $\begin{array}{c}0.711 \\
0.499^{*}\end{array}$ \\
\hline
\end{tabular}

* = significant (at $5 \%$ level); ** = highly significant (at1\% level).

Among the yield contributing characters plant height had negative interaction with spikes per plant, spike length, grains per spike, 100-grain weight, days to maturity and harvest index. Spikes per plant was highly significant but negatively correlated with 100-grain weight. Bhuyian et al. (1998) found similar results. It is observed that correlation between grains per spike and 100-grain weight was significant but negative. Both characters are primary yield components and share a common source for their development. Such negative correlation explains the mechanism of compensation between them in determining grain yield. Shamsuddin (1987) and Jaglan et al. (1997) reported similar negative association between them. Spikes per plant was positively correlated with grains per spikes, days to maturity and harvest index but negative correlation were observed with spike length and 100-grain weight. Genotypic and phenotypic correlations between spike length and grains per spike, 100-grain weight and harvest index were considerably high and positive. The interrelation between yield contributing characters exhibits that number of grains per spike was positively correlated with harvest index which indicated high portion of photosynthates was due to increase of number of grains per spike Number of grains per spike exhibited high and positive correlation with days to maturity and harvest index.

Genotypic correlation coefficients between these yield and yield contributing characters were generally higher than phenotypic correlation coefficients between them. But there are some exceptions to this observation. The correlation coefficients of spikes per plant with grains per spike and harvest index were high at phenotypic level, but they were low at genotypic level. This can be explained as such that environmental effect enhanced the correlation between them to become higher at phenotypic level. Positive relationship between yield and various yield contributing characters were reported by Shamsuddin and Abi-Antoun (1984).

The study of correlation among yield and yield contributing traits suggests that spikes per plant, grains per spike, spike length, 100-grain weight and harvest index were the most important characters which possessed positive association with grain yield per plant. Therefore, these characters could be utilized in breeding program to improve varieties for higher yield. 


\section{Path coefficient analysis}

Relationship between yield and yield contributing characters were studied in details through path coefficient analysis. Path coefficient analysis performed to disclose the causes and effects of chain relationships of different yield contributing characters with yield. Estimates of direct and indirect effects of yield contributing characters on grain yield per plant using genotypic correlation are presented in Table 5 and Fig.1 It was revealed that considerably highest positive direct effect on gain yield was exhibited by grains per spike followed by $100-$ grain weight, spikes per plant and harvest index. Mondal et al. (1997) obtained grains per spike, 100-grain weight and tillers per plant had positive direct effects on grain yield, whilst plant height had a negative direct effect on yield of bread wheat. Among them grains per spike and harvest index were highly correlated with grain yield at genotypic level. The direct effects of these characters on grain yield could be considered as causes of such high correlation. In addition harvest index also affected grain yield indirectly through grains per spike.

Table 5. Path coefficient analysis of eight yield contributing characters on grain yield/plant of spring wheat

\begin{tabular}{|l|c|c|c|c|c|c|c|c|}
\hline \multicolumn{1}{|c|}{ Characters } & $\begin{array}{c}\text { Plant } \\
\text { height } \\
(\mathrm{cm})\end{array}$ & $\begin{array}{c}\text { Spikes } \\
\text { par plant } \\
\text { (no.) }\end{array}$ & $\begin{array}{c}\text { Spike } \\
\text { length } \\
(\mathrm{cm})\end{array}$ & $\begin{array}{c}\text { Grains } \\
\text { per spike } \\
\text { (no.) }\end{array}$ & $\begin{array}{c}\text { 100-grain } \\
\text { weight } \\
\text { (g) }\end{array}$ & $\begin{array}{c}\text { Days to } \\
\text { maturity } \\
\text { (days) }\end{array}$ & $\begin{array}{c}\text { Harvest } \\
\text { index } \\
(\%)\end{array}$ & $\begin{array}{c}\text { Total } \\
\text { correlation } \\
\text { to yield }\end{array}$ \\
\hline Plant height (cm) & $-\mathbf{0 . 0 7 6}$ & -0.026 & -0.000 & -0.055 & 0.001 & 0.045 & -0.082 & -0.193 \\
\hline Spikes per plant (no.) & 0.004 & $\mathbf{0 . 5 5 1}$ & -0.001 & 0.222 & -0.745 & -0.071 & 0.048 & 0.008 \\
\hline Spike length (cm) & 0.013 & -0.187 & $\mathbf{0 . 0 0 2}$ & 0.129 & 0.279 & -0.015 & 0.031 & 0.252 \\
\hline Grains per spike (no.) & 0.004 & 0.127 & 0.000 & $\mathbf{0 . 9 5 9}$ & -0.516 & -0.088 & 0.104 & 0.590 \\
\hline 100-grain weight (g) & -0.000 & -0.435 & 0.000 & -0.525 & $\mathbf{0 . 9 4 3}$ & 0.088 & -0.020 & 0.051 \\
\hline Days to maturity (days) & 0.014 & 0.161 & 0.000 & 0.348 & -0.341 & $\mathbf{- 0 . 2 4 2}$ & -0.027 & -0.087 \\
\hline Harvest index (\%) & 0.022 & 0.094 & 0.000 & 0.358 & -0.066 & 0.024 & $\mathbf{0 . 2 7 9}$ & 0.711 \\
\hline
\end{tabular}

Bold figures indicate the direct effect

Residual effect $=0.382$

Spikes per plant and 100-grain weight although exhibited high and positive direct effects on grain yield but their correlations with grain yield were minimum. High negative indirect effect of spikes per plant through 100-grain weight reduced the correlation of the character with grain yield to be negligible. Similarly high and negative indirect effect of 100 -grain weight through spikes per plant and grains per spike caused the poor correlation of the character with grain yield. The character days to maturity had negative direct effect on grain yield, which suggests that the selection for early maturing lines with high yield is possible. The influence of plant height and spike length on gain yield was very little. These results are in line with Mondal et. al ( 1997)

Study of relationship between yield and yield contributing characters in spring wheat through genotypic and phenotypic correlations and path coefficients suggests that spikes per plant, grains per spike, 100-grain weight and harvest index were the most important characters as they exhibited high direct effects on grain yield per plant. Genotypic correlations of grains per spike and harvest index were highly significant and positive. Therefore, selection for these characters would give better response to yield improvement. 


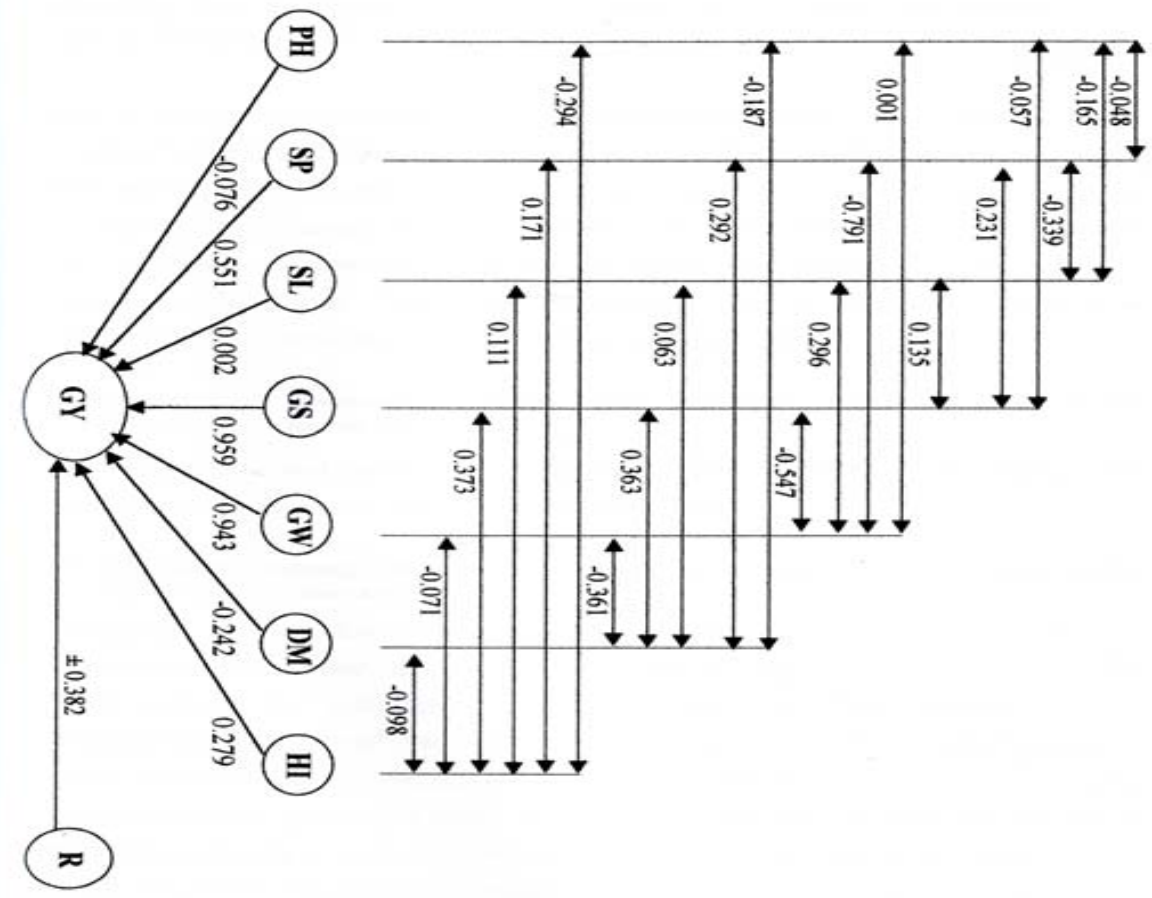

Fig. 1. Genotypic path diagram of yield contributing characters on grain yield per plant. Single arrow lines indicate path coefficients and double arrow lines indicate correlation coefficient. $\mathrm{PH}=$ plant height, $\mathrm{SL}=$ Spike length, $\mathrm{GS}=$ Grains per spike, $\mathrm{GW}=100-$ grain weight, $\mathrm{DM}=$ days to maturity, $\mathrm{HI}=$ Harvest index, $\mathrm{GY}=$ Grain yield per plant, $\mathrm{R}$ $=$ Residual effect

The residual effect of the present study was 0.382 indicating that he characters studied contributed $62 \%$ of the yield. It is suggested that maximum emphasis should be given on the above characters in selecting wheat with higher yield. It is also suggested that further study should be made with more characters to find out other traits which contribute rest of the percentage of the yield.

The genetic parameters, correlation and path coefficient analysis of the present study revealed that grains per spike, 100- grain weight, spikes per plant and harvest index were the most important traits to be selected for the development of modern wheat variety. The characters also showed moderate to high heritability and genetic advance in percentage of mean. Thus, the results suggest that higher number of grains per spikes, bold size grains, more spikes per plant and higher harvest index are the important yield contributing traits and thus plant selection based on these traits will be most effective.

\section{References}

Agarawal, R.K., Sharma, R., Sharma, G.S., Singh, R.B. and Nandon R. 1977. Variability land association of coleptile length and other traits in wheat. Indian J. Agric. Sci. 47: 234-236.

AL-Jibouri, H.A., Miller P.A. and Robinson H.F. 1958. Genotypic and environmental variation and correlation in upland cotton cross of interspecies origin. Agron, J. 50:633-636.

Amin, M.R., Barma, N.C. and Razzaque, M.A. 1992. Variability, heritability, genetic advance and correlation in durum wheat. RACHIS. 1(2): 30-32. 
Balchand, R.B. and Lodhi, G.P. 1994. Studies on variability for some agronomic traits in whea (Triticum aestivum L.) Agric. Sci. Digest. 14(1): 13-14.

Bhuyian, M.M.A., Shamsuddin, A.K.M., Uddin, M.K., Islam, M.M., and. Begum, S.N. 1998. Coefficients of variation, genetic parameters, correlation and path analysis in bread wheat. Bangladesh J. Nuclear Agric. 14: 9-14.

Burton, G.W. and De Vane E. W. 1953. Estimating heritability in tall fescue (Festuea arundenaceae) from replicated clonal material. Agron. J. 45:476-481.

Deswal, R.K., Grakg, S.S., and Berwal, K.K. 1996. Genetic variability and characters association between grain yield and its components in wheat. Annals Biol. Ludhiana. 12(2): 221-224.

Dewey, D.R and Lu. K.H. 1989. A correlation and path coefficient analysis of components of crested wheat grass seed production. Agron. J. 51:515-518.

Ehdaie, B. and Waines, J.G. 1989. Genetic variation, heritability and path analysis in land races of bread wheat from South Western Iran. Euphytica. 41: 183-190.

Hanson, G.H., Robinson H.F. and Comstock, R.E. 1956. Biometrical studies on yield in segregating populations of Korean Lespidiza. Agorn. J. 48:268-272.

Jaglan, R.S., Tanden, J.P. and Munshi, S. 1997. Correlation studies in tall versus dwarf populations of bread wheat (Triticum aestivum L.). Indian J. Agric. Res. 31(1): 19-22.

Johnson, H.W., Robinson, H.F. and Comstock, R.E. 1955. Estimation of genetic and environmental variability in soybean. Agron J. 47: 314-318.

Mondal, A.B., Sadhu, D.P. and Sarkar, K.K. 1997. Correlation and path analysis in bread wheat. Env. \& Ecol. 15(3): 537-539.

Shamsuddin, A.K.M. 1987. Path analysis on bread wheat. Indian J. Agric. Sci. 57(1): 47-49.

Shamsuddin, A.K.M. and Abi-Antoun M. 1986. Nature of gene action controlling yield and yield components in spring wheat. Bangladesh J. Agric. 11(3): 1-11.

Sharma, D.J., Yadav, R.K. and Sharma, R.K. 1995. Genetic variability and association of some yield components in winter $\times$ spring nursery of wheat. Adv. PI. Sci. 8 (1): 95-99.

Shoran, J. 1995. Estimation of variability parameters and path coefficients for certain metric traits in winter wheat (Triticum aestivum L. em. Thell.). Indian J. Genet. 55(4): 399-405.

Singh, K.N., Ahmad, Z., Gupta, M.P. and Singh, A.K. 1978. Variability, heritability and genetic advance for some metric traits in macaroni wheat. Indian J. Agric. Res. 12(2) : 237-240. 